\title{
ENTREPRENEURSHIP: ENTREPRENEURS TO WIN THEIR SUSTAINABLE COMPETITIVE ADVANTAGES WITHIN GLOBALIZATION ERA
}

\author{
Lenny Gunawan \\ Department International Business Management, Universitas Ciputra \\ UC Town, CitraLand, Surabaya, Jawa Timur 60219 \\ lenny.gunawan@ciputra.ac.id
}

\begin{abstract}
The purpose of this paper is to discuss globalization's impacts on the world's financial characteristics today. The findings inform that globalization promotes entrepreneurship because through globalization, financial markets have grown to be more efficient and flexible which can be seen through lower transaction costs, less binding financial regulations than before, less governments' intervention within private sector and national economy structures, increasing number of market participants which leads to more access to information. Thus, globalization does create a better environment for entrepreneurs in achieving their competitive advantages and further to sustain them. This research was done by collecting data from papers, journals, modules, and internet databases. The data was analyzed and then concluded. Having applied the analytical process, it can be concluded that globalization does promotes entrepreneurship because it enables entrepreneurs to gain greater benefits at a certain degree of freedom than before in order to achieve and maintain their competitive advantages.
\end{abstract}

Keywords: globalization, entrepreneurship, market's efficiency, sustainability competitive advantage

\begin{abstract}
ABSTRAK
Tujuan dari makalah ini ialah untuk membahas pengaruh globalisasi terhadap karakteristik finansial dunia dewasa ini. Hasil temuan menunjukkan bahwa globalisasi mendukung entrepreneurship karena melalui globalisasi, pasar financial telah berkembang menjadi lebih efisien dan fleksibel yang terlihat melalui biaya transaksi yang lebih rendah, peraturan keuangan yang lebih tidak mengikat dari sebelumnya, intervensi pemerintah yang lebih kecil dalam sector swasta dan struktur ekonomi nasional, dan jumlah peserta pasar yang meningkat sehingga akses terhadap informasi lebih luas. Oleh karena ini, globalisasi telah menciptakan lingkungan yang lebih baik bagi para entrepreneur dalam meraih keuntungan kompetitif mereka dan untuk mempertahankannya setelah itu. Penelitian ini dilakukan dengan mengumpulkan data dari makalah-makalah, jurnal, modul, dan basis data di Internet. Data-data tersebut dianalisis lalu disimpulkan. Setelah proses analisis, dapat disimpulkan bahwa globalisasi benar-benar mendukung entrepreneurship karena membuat para entrepreneur dapat meraih keuntungan yang lebih besar dengan tingkat kebebasan tertentu daripada sebelumnya untuk meraih dan mempertahankan keuntungan kompetitif mereka.
\end{abstract}

Kata kunci: globalisasi, entrepreneurship, efisiensi pasar, kelestarian, keuntungan kompetitif 


\section{INTRODUCTION}

\section{A Brief Overview of the Literature}

The word globalisation itself has been heard and become so familiar within the recent two decades. Globalization has raised different reactions within the society. Some agree and give full supports to it; nonetheless many are being reluctant and unprepared on getting involved, why so? According to the currency transaction tax website, it is because economic globalization involves two main lines: trade liberalization and financial liberalization.

According to the International Monetary Fund (1997), globalization refers to the interdependence within countries worldwide which has grown significantly within economic field through rising volume and variety of cross-border transactions, free international capital flows, also through more rapid and widespread diffusion of technology. Thus, many businesses and entrepreneurs are required to work efficiently in order to keep up with the globalization's rapid pace.

Societies who prefer to keep their businesses' access internally and those who are unprepared for liberalization might undergo great pressures on operating their businesses because they could not keep up with the requirements and follow the fast-paced the way global business is conducted today, thus there are reluctance reactions on accepting it. Those parties, who are not ready or purposely intended to keep their markets less exposed from other parties, will also be unwilling to loosen their controls over the financial and trade regulations.

Nowadays, globalization's role has increased significantly and given an unavoidable impact to finance today, business has grown into a world-wide fast-paced simultaneous economic activities where one economic transaction in one side of the world able to impact other economic entities in most parts of the world within short period of time. Globalization does stimulate greater transaction volume, greater range of financial products, more flexible capital flows within countries, also greater chances upon market access throughout the world. Those aspects above have incorporated changes in businesses that actually have a good impact, which is the fact that through globalization, entrepreneurship increases economic growth and development.

Therefore it is safe to say that globalization refers to the constantly changing global environments due to the face-paced business conduct since globalization era has been accelerated at the late 90'ish. The main question we need to address then, how to deal with these changes while still sustaining the firm's position or move even further to the top of the game?

\section{Winning Competitive Advantages within Globalization Era}

Change is ubiquitous in every industry within all geography in every firm. Change can come from inside or outside the firm (Brown \& Eisenhardt, 1998). Within their book they clearly address that companies have to deal with this changes and even embraces them in order to survive by doing the following actions which are: reacting, anticipating and finally leading the changes.

Reacting is a self-protective action which unlikely to create new opportunities however it is necessary to protect a firm from being out of the business. Second, anticipating is a preventive action where a firm is able to predict what is coming and reading the symptoms of the way the industry is heading, thus they will also try to adapt by changing some business area and/or environment which are still within their power. Third the utmost position is leading: means the firm is in charge of creating the changes, possessing the ability to force the other firms within the same industry to follow the games, the pace, the market, the products, the environment or even the rules the leader has created 
thus the particular firm possess the power on showing the path where the industry is heading. Further information is available in Figure 1.

Having said that, entrepreneurs in order to succeed would need to gain their competitive advantages, according to Porter (1985), competitive advantage is: a firm which sustains profits that exceed the average for its industry, the firm is said to possess a competitive advantage over its rivals. The goal of much of business strategy is to achieve a sustainable competitive advantage.” He identified two basic types of competitive advantage which are cost advantage and differentiation advantage. Further information can be attained from Figure 2.

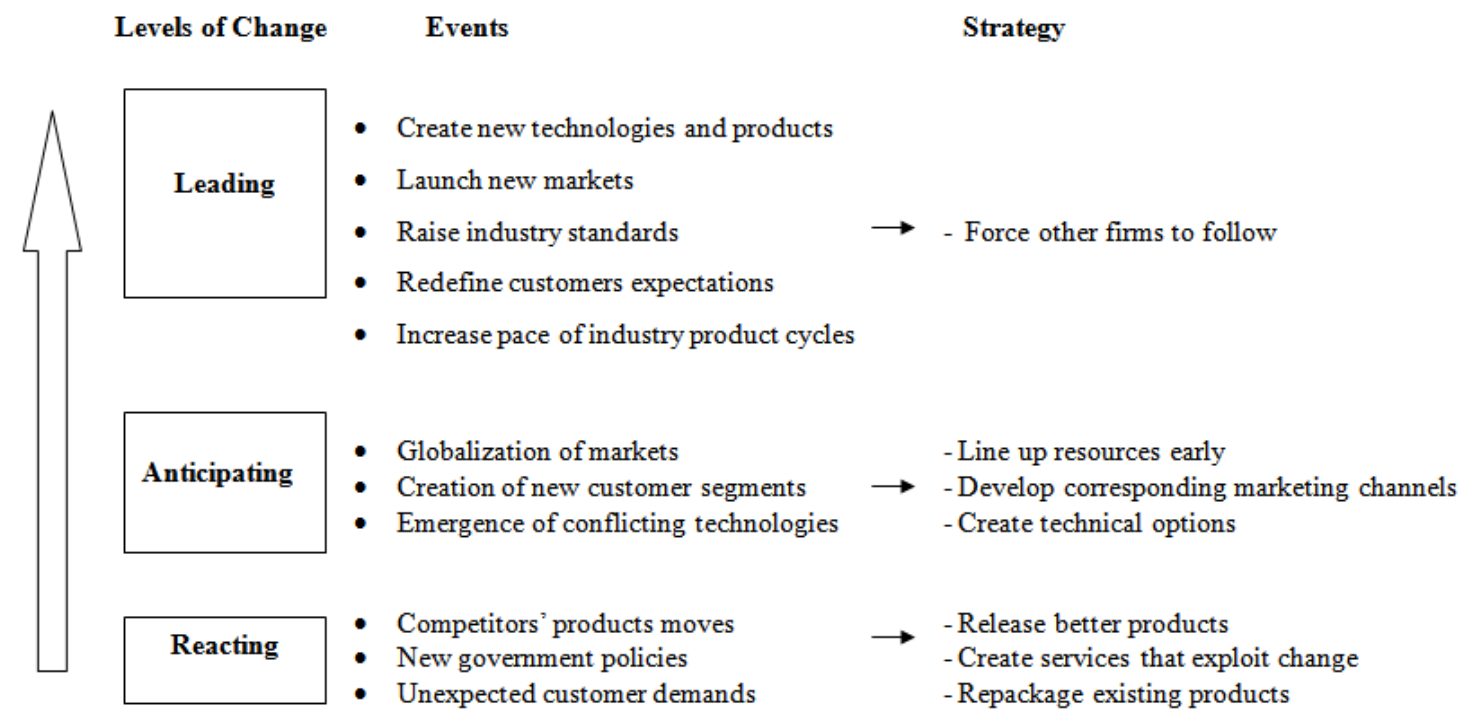

Figure 1 Brown \& Eisenhardt’s Managing the Strategic Challenge of Change Model (1998)

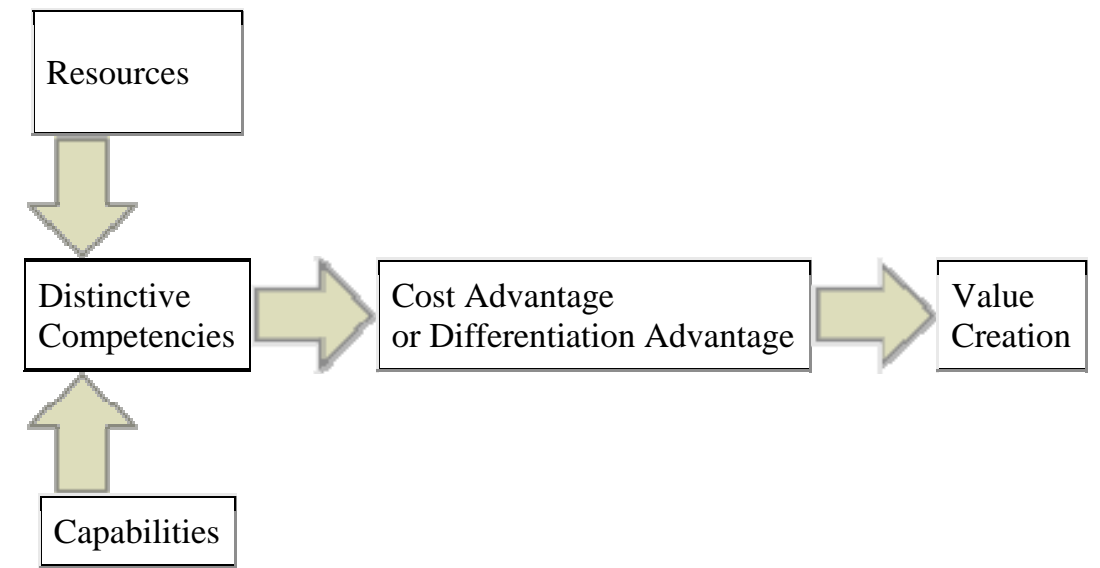

Figure 2 Michael Porter’s Model of Competitive Advantage (1985)

Therefore, we can conclude here that firms which own the leading power they also hold competitive advantage over their rivals and outperform the others through cost and/or differentiation advantages within the industry. 


\section{Globalization Enhances Markets’ Efficiency and Flexibility}

According to OECD (1999), globalization promotes efficient financial markets. The statement can be proven by looking at the effect of globalization in business. Because of the globalization pressure, governments have been pushed to alleviate trade barriers and unnecessary regulations, they are also being forced to some extent to open their economies to the private sector, allowing them to participate and contribute greater contributions within the economy without the same level of government supervision as before thus the phenomena gives greater flexibility level for entrepreneurs on conducting their business since the changes have given them more conducive business environments.

Globalization also enhances market efficiency, let us go through what is market efficiency that is applicable within globalization context, (FinanceProfessor, 2007), an efficient market is said to have price that already reflects the available information and thus buying or selling the stock should, on average, return you only a "fair" measure of return (after transaction costs) for the associated risk. The definition gives us a clear description that within globalization era, market participants are gaining almost the same amount of return under an efficient market due to the widespread and diffusion of technology that allows information and data to flow simultaneously and fast to address businesses' needs and therefore maximize entrepreneurs' chances on getting the same level information almost at the same time.

Adding to that, OECD (1999) states that entrepreneurship requires efficient financial markets, a flexible labor market, a simpler and more transparent corporate taxation system, and bankruptcy rules to be better adapted to the business world realities. Along with the paper written by OECD, Ariff, et. Al. (1998) states that: "Liberalization leads to higher financial market efficiency via greater capital mobilization". Since globalization leads to trade liberalization and financial liberalization, the greater participant numbers in business indicate more efficiency because it also means entrepreneurs will have those greater choices of products, services and other resources to support their businesses in more competitive prices. Consequently globalization constructs more competitive environments. Accordingly, all parties will be forced to conduct business in more efficient ways in order to survive in efficient markets.

\section{Globalization Increases Business Competition}

Globalization also forces countries to open their economy towards the arrival of foreign labors, products/services and other resources according to Hill (2007), by doing so, many parties need to adjust their commerce and financial regulations to a certain degree in order to adjust with the global business requirements. From the entrepreneurs' side, they actually gain benefits from the arrival of foreign resources and the less restricted global regulations because it accommodates them with more competitive rates when they intend to hire staffs, managers or professionals with better skills, knowledge and competencies.

On the other hand, globalization allows entrepreneurs face the increasing level of competitions as the result of greater global market access allowed by governments around the world. Secondly, more educated market participants and the fast improvement within the technology era will channel information and data to participants' specific needs allowing them to regain and maintain their competitive advantages in a more conducive regulation and governments' requirements than preglobalization era. Therefore we can conclude that globalization also creates higher level of business competition among its participants. 


\section{Successful Entrepreneurs’ Characteristics}

It is honest to say that not all entrepreneurs are destined to be successful; we will need to figure out which entrepreneurs are fulfilling the requirements to compete in intense competition level that globalization era has created. Entrepreneurs are those who bear the risks and uncertainty while creating new businesses. Their goals are achieving profit and business growth by taking and creating opportunities and using their resources in achieving their business targets.

From the definition above then, the successful entrepreneurs has to show passion in the business the person is doing, being independent in conducting his/her business, having the sensitivity to see market's needs and the upcoming trend, being creative and innovative in seizing and spotting or even creating the new opportunities within the existing or new markets, able to take risk but also able to let go when it is overpowering his/her capabilities, has to own persistency in keep doing and trying the best way of conducting business, and finally practice good ethical behavior within day to day operations.

\section{Globalization Requires Adequate Business Transparent Level}

The fifth phenomena will be the need to provide a simpler and more transparent corporate taxation system. Contributing to the increasing interdependence within countries worldwide, the rising volume and variety of cross-border transactions and the free international capital flows, certainly entrepreneurs will be required to provide more transparent financial reports, satisfactory compliance to corporate governance and adequate disclosure level regarding their business systems since different governments, parties, participants and investors are involved. Especially when entrepreneurs own and intend to make their businesses go-public (including to be listed within other developed stock markets), they surely will also be acquired to provide this level of scrutiny in order to gain investor's confidence and growing their businesses.

Having said that, it is safe to believe that globalization allows entrepreneurs to hold greater possibilities reaching a better level of market efficiency. These can be attained from greater access to the market that enables entrepreneurs to gather information faster and in more efficient and profitable ways through advance technology and communication innovations and systems.

\section{Globalization Promotes Entrepreneurship through Greater Opportunities}

Globalization also offers broader and more diverse financial products which can be used to reduce business' risks and costs, thus entrepreneurs and other market participants are supplied with more flexibilities to choose which products suits their needs the best. Ariff (1998) mentioned that liberalized market will be able to offer less transaction costs and lower interest rates thus markets will be more competitive and efficient under no suppression and unnecessary barriers.

Entrepreneurs will also benefit greater advantages from greater efficiency level within the market, in the forms of: no excessive tariffs, taxes, subsidies, quotas and less financial distortions such as: borders and domestic protections. As the result markets are enabled to trade with less binding regulations and with more flexibility which allow and provide entrepreneurs the better chances on gaining and maintaining their sustainable competitive advantages.

Adding to that, foreign investments and private sectors which are interested in doing business within the domestic markets as the result of globalization certainly will enable and creates new entrepreneurs to provide more job vacancies within that certain country in order reduce unemployment level and increase the particular country's economy level as well. In responding to globalization and entrepreneurship issue, we should start immediately to simultaneously intensifying our education and 
training fields. They need to be taken more seriously from now on because the better skills, knowledge and competencies the human resources within a country, the greater chances new businesses will be able compete and survive within the increasingly fast-paced and competitive global business environments has become.

\section{DISCUSSION}

Globalization has enabled entrepreneurs to gain greater benefits at a certain degree of freedom which allow them to achieve and maintain their competitive advantages. Globalization has given them the more conducive business environments which was not available as it is today in pre-globalization era. The more conducive environments have been created since governments and other parties have been forced to loosen their controls over the financial regulations and restrictions over the past decades.

Having said the positive impact globalization brings to entrepreneurship, in contrast we cannot deny that globalization has also been stiffening the business competition among market players. Thus we are required to intensify and develop our education and training fields in order to be able to keep up and answer the challenge of providing more competent human resources and increasing the country's economy level. After all, globalization and entrepreneurship create a win-win situation for the favourable environments it provides towards more efficient market and the business efficiency itself.

\section{CONCLUSION}

Entrepreneurship is actually promoted by globalization because globalization enhances the efficiency of financial markets and the market participant's flexibility on adopting the new changes which happens every now and then in global business today. Globalization also increases business competition level through the ability of providing more products, services, labour and other resources availability, it also provides the greater and faster access to information, data and the markets. It also accommodates market participants the lower transaction costs through lower interest rates and free capital flow throughout regions and borders. Moreover, globalization also requires adequate business transparency level through obliging businesses and entrepreneurs to provide satisfactory disclosure upon their financial statements, adopting the proper corporate governance implementation and also the indicating the business systems used on running their business in order to gain investor's confident and retain growth for their businesses. Finally globalization promotes entrepreneurship through greater opportunities by forcing countries to loosen their financial regulations such as: alleviate unnecessary tariff barriers, taxes, quotas and impose less binding financial regulations which overall helps entrepreneurs to achieve a better and more efficient way on conducting their business in order to gain their competitive advantage and finally sustain it within the constantly changing global business. 


\section{REFERENCES}

Brown, S. L., \& Eisenhardt, K. M. (1998). Competing on the Edge: Strategy as Structured Chaos. Boston, Massachusetts: Harvard Business School Press.

FinanceProfessor, (2007) Market Efficiency. Online, retrieved on 20 February 2008, from http://www.financeprofessor.com/488/notes/market_efficiency.htm

Hill, C. W. L. (2007). International Business: Competing in the Global Marketplace. New York: McGraw-Hill International Edition.

IMF (1997). World Economic Outlook: Globalization Opportunities and Challenges, Washington, D.C.

OECD (1999). Fostering Entrepreneurship. France: OECD Publishing.

Porter, M. E. (1985). Competitive Advantage: Creating and Sustaining Superior Performance. Free Press. 